\title{
Keberdayaan Pemuda Melalui Gerakan Pendidikan Etika Lingkungan Dalam Komunitas Garis Pena Jember
}

\author{
Wilda Tsani Nuranita, A.T. Hendra Wijaya, Linda Fajarwati \\ Pendidikan Luar Sekolah, Universitas Jember. Jl. Kalimantan No. 37, Tegal Boto, Jember 62811, \\ Indonesia \\ Email: wildatsani8@gmail.com
}

\begin{abstract}
Abstrak
Krisis etika lingkungan pada manusia saat ini memiliki pengaruh besar dalam kerusakan lingkungan. Perlu ditegaskan pula bahwa peran pemuda saat ini sangat berpengaruh dalam kondisi lingkungan. Penelitian ini menggunakan jenis penelitian deskriptif dengan pendekatan kualitatif. Tempat yang dipergunakan untuk penelitian berada di Komunitas Garis Pena Jember. Teknik penentuan informan dalam penelitian ini menggunakan teknik purposive sampling kemudian teknik dalam memperoleh data dari informan atau teknik wawancara menggunakan teknik snowball sampling. Teknik pengumpulan data dilakukan dengan metode observasi, wawancara dan dokumentasi. Supaya derajat kepercayaan terhadap data menjadi tinggi maka digunakan teknik peningkatan ketekunan, perpanjangan keikutsertaan, triangulasi. Analisis data dilakukan dengan analisis sebelum di lapangan dan analisis di lapangan. Hasil penelitian dalam penelitian ini adalah terdapat dua ukuran pemuda berdaya, yaitu kesadaran dan keinginan untuk berubah serta kerjasama dan solidaritas antar anggota. Demi tercapainya dua ukuran keberdayaan tersebut Komunitas Garis Pena Jember menggunakan strategi pembelajaran berbasis masalah dan strategi pembelajaran kooperatif sedangkan metode yang mereka gunakan yaitu metode diskusi dan metode pressing
\end{abstract}

Kata Kunci: keberdayaan pemuda, kesadaran, etika lingkungan, pendidikan etika

\section{Youth Empowerment Through Environmental Ethics Education Movement In Jember Garis Pena Community}

\begin{abstract}
The ethical crisis of the environment in humans today has a major influence on environmental damage. It also needs to be emphasized that the role of youth today is very influential in environmental conditions. This research uses descriptive research with a qualitative approach. The place used for research is in Jember Garis Pena Community.. The technique of determining informants in this study used a purposive sampling technique then the technique of obtaining data from informants or interview techniques used the snowball sampling technique. The technique of data collection is done by the method of observation, interviews and documentation. In order for the degree of trust in the data to be high, the technique of increasing persistence is used, an extension of participation, triangulation. Data analysis was carried out with prior field analysis and analysis in the field. The results of this research are two measures of empowered youth, namely awareness and desire to change and cooperation and solidarity among members. In order to achieve these two measures of empowerment the Jember Pena Line Community uses problem-based learning strategies and cooperative learning strategies while the methods they use are discussion methods and pressing methods.
\end{abstract}

Keywords: youth empowerment, awareness, environmental ethics, ethical education 


\section{Learning Community: Jurnal Pendidikan Luar Sekolah, 3 (2), September 2019 - 2 \\ Wilda Tsani Nuranita}

\section{PENDAHULUAN}

Krisis etika lingkungan pada manusia saat ini memiliki pengaruh besar dalam kerusakan lingkungan. Masalah lingkungan di Indonesia saat ini adalah salah satu masalah yang sangat serius dan belum mendapat perhatian dari pemerintah dan juga masyarakat secara umum. Situasi tersebut berlaku di berbagai kota-kota seluruh Indonesia, demikian juga yang terjadi di Jember. Masyarakat Jember masih kurang dalam hal rasa cinta dan sikapnya dalam upaya menjaga kelestarian lingkungan. Salah satu contoh dari pernyataan tersebut adalah masih banyaknya penggunaan plastik (kresek), dan kurangnya kesadaran untuk membuang sampah pada tempatnya. Hal ini terbukti masih banyak masyarakat Jember yang membuang sampah di sungai-sungai. Situasi-situasi tersebut apabila kedepan tidak ada penanggulangan dan upaya pencegahan, maka dapat dipastikan bahwa kerusakan lingkungan di Jember akan semakin memburuk. Untuk mencegah dampak buruk dari kurangnya menjaga lingkungan dibutuhkan upaya strategis dan berkesinambungan. Salah satu langkah strategis dan berkesinambungan yang dimaksud adalah pendidikan. Pendidikan merupakan wahana yang paling tepat untuk internalisasi dan transformasi keyakinan, nilai, pengetahuan dan keterampilan.

Lingkungan hidup, tidak dapat dipungkiri merupakan sumber kehidupan manusia. Manusia dan lingkungan berhubungan dan saling memiliki ketergantungan antara satu dengan lainnya. Saat ini banyak sekali masalah-masalah yang timbul akibat kelalaian manusia pada lingkungan. Ekologi, sebagai disiplin ilmu yang mempelajari hubungan saling mempengaruhi antara manusia dengan lingkungannya telah memberikan gambaran yang jelas mengenai hubungan tersebut. Hubungan antara satu organisme dengan yang lainnya, dan antara organisme tersebut dengan lingkungannya.

Krisis lingkungan yang terjadi selama ini, sebenarnya bersumber dari kesalahan cara pandang manusia mengenai dirinya, alam dan tempat tinggal manusia secara keseluruhan dalam satu ekosistem. Kekeliruan dalam memandang alam serta kekeliruan menempatkan diri dalam konteks alam semesta, menghasilkan pola perilaku yang mengakibatkan kerusakan alam lingkungan. Atas alasan tersebut maka harus dilakukan pembenahan cara pandang dan perilaku manusia dalam berinteraksi, baik dengan sesama manusia maupun dengan lingkungan alam dalam keseluruhan ekosistem. Seperti ditegaskan pada awal tulisan ini bahwa melalui pendidikan, cara pandang manusia terhadap lingkungan dapat diubah. Melalui komunitas-komunitas yang peduli terhadap lingkungan. Justru komunitas yang ada di masyarakat ini mempunyai satu keunggulan, di mana mereka ada di dalam masyarakat itu sendiri yang artinya mereka mengetahui masalah-masalah lingkungan secara langsung. Jember mempunyai satu komunitas peduli terhadap kelestarian lingkungan, yaitu Komunitas Garis Pena.

Komunitas Garis Pena adalah komunitas pecinta lingkungan yang berusaha dan bergerak untuk ikut andil dalam menjaga kelestarian lingkungan serta mengatasi serta memberikan upaya perubahan terhadap permasalahan lingkungan di Jember. Terbentuknya komunitas ini didasari dengan banyaknya masalah lingkungan yang muncul di Jember yang salah satunya adalah masalah tentang sampah. Komunitas Garis Pena yang beranggotakan para pemuda Jember yang berkumpul dengan visi yang sama yaitu merubah kota Jember menjadi lebih baik soal lingkungan. Banyak program kerja yangtelah dilakukan komunitas Garis Pena dalam menanggulangi masalah lingkungan. Kegiatan yang dimaksud antara lain adalah diskusi mengenai masalah lingkungan, diklat yang menanamkan jiwa pelestari, menanam pohon dalam memperingati hari bumi, dan kampanye diet sampah dan lain-lain. Hal itu dilakukan dan menjadi titik fokus Komunitas Garis Pena untuk ikut membantu mengurangi masalah lingkungan masyarakat Jember.

\section{METODE}

Penelitian ini menggunakan jenis penelitian deskriptif dengan pendekatan kualitatif. Peneliti melakukan penelitiannya di Komunitas Garis Pena Gebang Jl. Teratai gang XVI Blok 1 No.2 Jember, Jawa Timur. berdasarkan metode purposive area. Teknik 


\section{Learning Community: Jurnal Pendidikan Luar Sekolah, 2 (1), September 2019 - 3 \\ Wilda Tsani Nuranita}

penentuan informan dalam penelitian ini menggunakan teknik purposive sampling kemudian teknik dalam memperoleh data dari informan atau teknik wawancara menggunakan teknik snowball sampling.

Teknik pengumpulan data dilakukan dengan metode observasi, wawancara dan dokumentasi. Supaya derajat kepercayaan terhadap data menjadi tinggi maka digunakan teknik peningkatan ketekunan, perpanjangan keikutsertaan, triangulasi. Analisis data dilakukan dengan analisis sebelum di lapangan dan analisis di lapangan. Sehngga dapat dikatakan bahwa data yang diraih bnear-benar valid

\section{HASIL DAN PEMBAHASAN}

Keberdayaan pemuda adalah suatu hasil dari proses pemberdayaan dimana pemuda menjadi subjeknya dan pemuda menjadi sasaran keberhasilan suatu program pemberdayaan, sehingga pemuda mampu dikatakan berdaya apabila pemuda mampu menjadi ujung tombak penerus bangsa dengan status "keberdayaan" itu sendiri. Kajian-kajian konseptual tentang pemberdayaan menyajikan banyak indikator keberdayaan. Empat di antaranya menyangkut derajat keberdayaan, yakni: a. Tingkat kesadaran dan keinginan untuk berubah (power to). b. Tingkat kemampuan meningkatkan kapasitas untuk memperoleh akses (power within). c. Tingkat kemampuan menghadapi hambatan (power over). $\mathrm{d}$. Tingkat kemampuan kerjasama dan solidaritas (power with). Terdapat empat indikator kesadaran yang masing-masing merupakan suatu tahapan bagi tahapan berikutnya dan menunjuk pada tingkat kesadaran tertentu, mulai dari yang terendah sampai yang tinggi, antara lain: pengetahuan, pemahaman, sikap, dan pola perilaku (tindakan). Penelitian ini mengambil sub fokus tingkat kesadaran dan keinginan untuk berubah serta tingkat kemampuan kerjasama dan solidaritas. Tingkat kesadaran dan keinginan untuk berubah merupakan hal dasar dalam merubah seseorang menjadi pribadi lebih baik hal ini sesuai dengan keberdayaan pemuda yang ingin diteliti. Dibuktikan dengan perubahan sikap anggota komunitas garis pena yang awalnya awam akan lingkungan menjadi sadar bahkan peduli terhadap ligkungam. Hal lain yang diungkap adalah tingkat kemampuan kerjasama dan solidaritas, karena Komunitas Garis Pena adalah komunitas pemuda yang beranggotakan beberapa pemuda yang didalamnya membutuhkan kerjasama (team work), dan tingkat solidaritas tinggi antar anggota.

Etika lingkungan erat kaitannya dengan pendidikan. Pendidikan merupakan salah satu upaya potensial dalam mengatasi krisis lingkungan yang terjadi saat ini dan masa yang akan datang. Pendidikan yang disampaikan di lingkungan komunitasakan lebih efektif menyentuh dan melekat pada diri pemuda. Ada beberapa proses pembelajaran pendidikan lingkungan hidup yaitu: 1) Strategi Pembelajaran, 2) Perencanaan Pembelajaran PLH, 3) Metode Pembelajaran PLH, 4) Evaluasi Pembelajaran. Peneliti mengambil strategi pembelajaran dan metode pembelajaran dari konsep yang ditawarkan Suaedi dan Hammado Hantu. Hal ini dilakukan karena dengan strategi dan metode pembelajaran yang baik akan mempengaruhi tingkat keberdayaan pemuda.

Kabupaten Jember tergolong wilayah perkampungan yang padat, dan kondisinya sangat memperihatinkan. Memo X tanggal 18 September 2017 merunut aliran sungai Rembangan atau tepatnya di wilayah perkampungan di belakang Rumah Sakit Paru-paru Kreongan Jember hasilnya terdapat tumpukan sampah yang cukup mengganggu aliran sungai. Hal ini tentu tidak hanya terjadi pada daerah tersebut tetapi di berbagai wilayah aliran sungai lainnya masih sangat banyak sampah-sampah rumah tangga yang bertebaran. Tidak hanya mengganggu aliran sungai, banyak dampak lain yang akan timbul akibat hal tersebut. Misalnya pencemaran air, gangguan kesehatan, dan masih banyak lagi. Hal tersebut di atas tentu menjadi urgensi permasalahan etika lingkungan di Jember.

Komunitas Garis Pena Jember berdiri pada tanggal Empat Belas Bulan September Tahun Dua Ribu Tiga Belas (14/09/2013) pada waktu 20:45 WIB. Pendirinya adalah Rizal, Diki Maulana, dan Andika Gayuh yang merupakan pemuda di Jember. Organisasi ini berkedudukan atau bertempat di Gebang Jl. Teratai gang XVI Blok 1 No.2 Jember, Jawa Timur. Komunitas Garis Pena lahir karena keresahan pemuda terkait kepedulian 


\section{Learning Community: Jurnal Pendidikan Luar Sekolah, 3 (2), September 2019 - 4}

Wilda Tsani Nuranita

masyarakat akan kelestarian lingkungan khususnya di kota Jember. Atas dasar pemikiran itulahketiga pemuda tersebut berinisiatif mendirikan sebuah komunitas, yang akhirnya bernama Komunitas Garis Pena. Mereka berlatar belakang pemuda yang menyukai hiking yang sadar akan pentingnya menjaga lingkungan.

Hasil Hal yang telah dilakukan oleh Komunitas Garis Pena Jember adalah dengan membangkitkan rasa ingin tahu para anggotanya untuk kemudian dari sana setiap anggota ditanamkan rasa cinta terhadap lingkungan dan pendidikan etika lingkungan. Seperti yang kita tahu Paradigma Biosentrisme berpendapat bahwa tidak benar apabila hanya manusia yang mempunyai nilai, akan tetapi alam juga mempunyai nilai pada dirinya sendiri yang terlepas dari kepentingan manusia. Bahwa manusia dan alam itu memiliki nilai yang sama. Keberdayaan kedua diukur melalaui tingkat kemampuan kerjasama dan solidaritas dalam menghadapi masalah lingkungan. Sebagai sebuah organisasi, Komunitas Garis Pena membutuhkan kekompakan dan solidaritas antar anggota. Kekompakan dan solidaritas tidak akan lepas dengan kata kebersamaan. Kekompakan suatu kelompok ditandai dengan kuatnya hubungan antar anggota tim yang merasakan saling ketergantungan dalam urutan tugas, ketergantungan hasil yang ingin dicapai, dan komitmen tinggi sebagai bagian dari sebuah tim.

Hal tersebut tidak lepas dari pendidikan yang diberikan oleh komunitas garis pena melalui strategi pembelajaran berbasis masalah. Strategi ini adalah teknik untuk membantu anggota agar memahami dan menguasai materi pembelajaran dengan menggunakan strategi pemecahan masalah. Kedua adalah strategi pembelajaran kooperatif atau cooperative learning yang menekankan kepada proses kerja sama dalam suatu kelompok yang biasa terdiri atas 3 sampai 5 orang siswa untuk mempelajari suatu materi akademik yang spesifik sampai tuntas. Juga tidak lepas dari metode pembelajaran yang digunakan dalam Komunitas Garis Pena adalah metode diskusi dan metode pressing. Metode diskusi dimaknai sebagai kegiatan tukar menukar informasi, pendapat dan unsur-unsur pengalaman secara teratur dengan maksud untuk mendapat pengertian yang sama, lebih jelas dan lebih teliti tentang sesuatu atau untuk mempersiapkan dan merampungkan keputusan bersama. Metode pembelajaran kedua adalah metode pembelajaran pressing atau stressing. Metode pressing adalah metode yang menekan aktifitas mental dan fisik agar calon anggota didik dapat bertahan dan keluar dari tekanan yang dihadapi. Metode ini diyakini Komunitas Garis Pena dapat meningkatkan daya tahan - secara psikologi dan fisik - dalam menghadapi tekanan.

\section{SIMPULAN}

Simpulan dari penelitian ini adalah keberdayaan pemuda anggota Komunitas Garis Pena yang semula awam atau tidak tahu tentang pendidikan etika lingkungan, sekarang mereka memiliki pengetahuan terhadap lingkungan. Bahkan mereka memiliki kepeduli terhadap pentingnya menjaga lingkungan. Adapun bentuk-bentuk kepedulian pemuda terhadap lingkungan antara lain, 1) memiliki jiwa pelestari, 2) mau menyuruarakan ajakan positif melalui tulisan-tulisan yang bermanfaat mengenai lingkungan, 3) penanam pohon dalam memperingati hari bumi, 4) membuang sampah pada tempatnya sesuai dengan pengelompokan jenis sampah. Keberdayaan yang dimaksud tidak dapat lepas dari bentuk pendidikan yang diberikan Komunitas Garis Pena kepada anggotanya. Pendidikan yang dimaksud meliputi pendidikan untuk memantik kemauan diri - anggotanya untuk berubah dan juga memiliki kemampuan solidaritas dan kerjasama antar anggota. Hal itu dilakukan dengan dua strategi pembelajaran yaitu strategi pemebelajaran berbasis masalah dan startegi pembelajaran kooperatif. Keduanya disertakan dua metode pembelajaran yaitu metode pembelajaran berbasis masalah yang menuntut para calon anggotanya menghadapi masalah kemudian menyelesaikannya di lapangan dan metode pembelajaran pressing di mana kemampuan mental - dan fisik menjadi tujuan utama dalam membentuk karakter diri sebagai pemuda. Semua proses tersebut dilakukan Komunitas Garis Pena untuk membentuk karakter pemuda sekaligus sebagai bukti keberdayaannya yang 
Learning Community: Jurnal Pendidikan Luar Sekolah, 2 (1), September 2019 - 5

Wilda Tsani Nuranita

cinta lingkungan dan membantu Jember dalam mengatasi krisis etika lingkungan.

\section{DAFTAR PUSTAKA}

Firmansyah, H. (2012). Ketercapaian Indikator Keberdayaan. Jurnal Agribisnis Perdesaan, http://download.portalgaruda.org/ar ticle.php?article $=96365 \&$ val $=2296$.

Suaedi, \& Hammado Hantu. (2016). Pembelajaran Pendidikan Lingkungan Hidup . bogor: PT Penerbit IPB Press.

Soekanto. 2002. sosiologi suatu pengantar. raja grafindo persada (rajawali perss.) 